\title{
Increasing Tourism Industry's Competitiveness Through Human Resources Planning
}

\author{
R. Rofaida \\ Management Study Program \\ Universitas Pendidikan Indonesia \\ Bandung, Indonesia \\ Email: rrofaida@yahoo.com
}

\begin{abstract}
Tourism sector's contribution to Gross Regional Domestic Product was very significant. In the employment aspect, this sector also plays an important role. The purpose of this research are mapping and conducting analysis of the formal labor market related with the employment potential, mapping and conducting analysis of the current potential of the tourism human resources, as well as developing the human resource planning to improve their competitiveness. The subjects of the study were hotels and restaurants in Bandung city. Hotels and restaurants are selected because this sector provided the largest contribution to the tourism development as seen from its financial contribution. The method used was survey method. The mapping and analysis of the formal labor market and tourism human resources potential were conducted using SWOT analysis. Tourism human resource planing will be focused on job opportunity expansion plan, the quality / competence improvement plan and entrepreneurship development. The result of the study is expected to be input in the preparation of human resources planning policy to improve competitiveness
\end{abstract}

Keywords : tourism sector, human resources planning, competitiveness

\section{INTRODUCTION}

Tourism sector plays a strategic role in the economy of Bandung city. The establishment of the tourism sector is strongly related with the hotel and restaurant industry development. Mostly tourists need facilities for accommodation and food. Hotels and restaurants become the primary choice. [1] The continuous increasing number of visits is a profitable investment opportunity for the hotel and restaurant sector. Employment potential of this sector is relatively high as seen from several indicators namely the sector's contribution to Bandung GDP, the contribution of the sector in employment and the business population growth.

Tourism sector's contribution to Gross Regional Domestic Product (GDP) in 2010-2013 was very significant. Trading, hotels and restaurants sectors gave the highest contribution of all sectors of the economy. More can be seen in Table 1. The contribution of this sector to Bandung GDP increased from $39.82 \%$ in 2010 to $42.62 \%$ in 2013 . This illustrates that in the coming three years, the economic potential of this sector will remain high and become a mainstay. [2]

\section{TABLE I. BANDUNG Gross Regional Domestic Product}

\begin{tabular}{lllll}
\hline & $\mathbf{2 0 1 3}$ & $\mathbf{2 0 1 2}$ & $\mathbf{2 0 1 1}$ & $\mathbf{2 0 1 0}$ \\
& $\mathbf{\%}$ & $\mathbf{\%}$ & $\mathbf{\%}$ & $\mathbf{\%}$ \\
\hline Agriculture & 0,18 & 0,19 & 0,19 & 0,20 \\
$\begin{array}{l}\text { Pertambangan } \\
\text { Industri Pengolahan }\end{array}$ & - & - & - & - \\
$\begin{array}{l}\text { Electricity and } \\
\begin{array}{l}\text { Water } \\
\text { Building }\end{array}\end{array}$ & 22,17 & 22,42 & 24,27 & 25,45 \\
$\begin{array}{l}\text { Trading, hotel, and } \\
\text { restaurant }\end{array}$ & 2,51 & 2,45 & 2,40 \\
$\begin{array}{l}\text { Transportation/ } \\
\text { Communication }\end{array}$ & 11,62 & 11,56 & 11,27 & 11,05 \\
$\begin{array}{l}\text { Bank/ financial/ } \\
\text { housing }\end{array}$ & 5,34 & 5,33 & 5,26 & 5,27 \\
Service & 10,21 & 10,56 & 10,64 & 10,78 \\
Total & 100 & 100 & 100 & 100 \\
\hline
\end{tabular}

a. Source: BPS Kota Bandung, 2014

In the employment aspect, this sector also plays an important role. There was a growing number of people working in the trading, hotel and restaurant from 369.161 people (in 2011) up to 396.304 people in 2013. (2) In the business population, there was an increasing number of five-star hotel during the period 2007-2012 from 61 in 2007 to 84 in 2012 with an increase rate of $23 \%$ within five years. It is projected that in the next five years the number of stars and non-stars hotel will be increasing.

However, one of the main problem related to human resources in the hotel and restaurant sector is that the employment is not maximized. Several factors causing this are related to the competitiveness of the human resources of the tourism sector itself. Competence of human resources in hotels and restaurants did not fulfill the national competence standard (SKKNI). Competence development becomes an absolute thing to be considered if it is associated with the policy of the Asean Economic Community in 2015 which enable foreign workers to enter Indonesia. This is a threat to Indonesian workers, if they cannot fulfill the service standards and certification nationally or internationally.

The research objective are mapping and conducting analysis of the formal labor market related with the 
employment potential, mapping and conducting analysis of the current potential of the tourism human resources, as well as developing the human resource strategy plan to improve their competitiveness.

\section{LITERATURE REVIEW}

\section{A. TOURISM HUMAN RESOURCES COMPETITIVENESS}

Competitiveness has become a very popular term in the last few decades. For the tourism industry, the World Economic Forum (WEF) published a report about the competitiveness of international tourism industry called "Travel \& Tourism Competitiveness Index". This report included the international competitiveness of 133 countries in the tourism field. This report sets the index of competitiveness of the tourism industry in a country based on 14 pillars consisting of a number of indicators. HR becomes one of the benchmarks in determining the competitiveness of the tourism industry in a country. Indonesia's competitiveness ranking for each indicator of competitiveness which based on its Human Resources (HR) is shown in Table 2 below:

TABLE II. INDONESIA TOURISM HR COMPETITIVENESS INDEX IN ASEAN IN 2009

\begin{tabular}{l|l|l|l}
\hline 1. & Brunei Darussalam & 52 & 5.17 \\
\hline 2. & Kamboja & 127 & 3.75 \\
\hline 3. & INDONESIA & 42 & 5.26 \\
\hline 4. & Malaysia & 30 & 5.56 \\
\hline 5. & Filipina & 69 & 5.05 \\
\hline 6. & Singapura & 1 & 6.29 \\
\hline 7. & Thailand & 57 & 5.16 \\
\hline 8. & Vietnam & 82 & 4.91 \\
\hline
\end{tabular}

From the table above, Indonesia tourism human resources is ranked third (after Singapore and Malaysia. As seen from the 10 Tourism HR indicators as the benchmark index of Tourism HR competitiveness by the WEF, the strength of Indonesia is on these indicators: the hiring and firing practice model, ease for foreign labor and extent of staff training. [3].

\section{B. Bandung Human Resource Plan Policy}

According to the vision and mission of Bandung city, the government's purpose is "Strengthening Bandung Citizens Prosperity by improving the formal employment opportunities in the sectors that become core competency ".

Bandung tourism human resources planning cannot be separated from the human resources planning policy in general. HR planning refers to the regulations set by the Bandung Government. The following explanation will discuss some of the legal basis of tourism human resource planning implementation in Bandung.

a) Law of the Republic of Indonesia Number 13 Year 2003 on Employment b) Bandung Regional Regulation No. 18 Year 2002 on the Implementation of the Employment in Bandung.

c) Strategic Plan of the Department of Labor Bandung year 2009-2013

\section{METHODOLOGY}

The subjects of the study were hotels and restaurants in Bandung city. Hotels and restaurants are selected because this sector provided the largest contribution to the tourism development as seen from its financial contribution. The method used was survey method. The method used was survey method. The Sample size are 30 business unit. The sample was taken using purposive sampling,. The data were collected using observation, interviews, surveys, expert justification, FGD, and a desk study. The observations used "one shoot" time coverage / cross sectional. The data analysis was performed with the help of SWOT analysis and then analyzed descriptively.

\section{RESULT AND DISCUSSION}

\section{A. SWOT Analysis for Mapping The Job Market and The Potential of The Recent Tourism HR}

The mapping and analysis of the formal labor market and tourism human resources potential were conducted using SWOT analysis. The results of field observations, surveys, and desk study shows the factors related to the tourism sector human resources existing condition that can be mapped in the form of a SWOT matrix (Table 3). SWOT analysis is an instrument of strategic management. Internal strengths and and weakness as well as external influences which can be opportunitie or threats are analysed in order to derive promising future strategies. [4] SWOT matrix identifies some aspects which become its strengths and weaknesses. In the other dimensions, SWOT matrix also identifies environmental factors / external factors which rise opportunities as well as threats for the development of tourism human resources.

One of the strength of Bandung tourism HR profiles is the availability of HR who have a fairly high level of education, high school or the equivalent. The relatively high level of education is expected to facilitate the implementation of the competence development program conducted by the government and private sectors.

The main weakness of Bandung tourism HR profiles is that the competence supply have not fulfill the requirements in the market which cause the employment level to be lower than $100 \%$, and, moreover, the number of the workforce with professional certificate is very low. Quality or competence problems has become a major and crucial problem. Competence development to fulfill the demands of the market and encouragement to participate in the certification program to enhance competitiveness are some important strategy to be applied

Opportunities arise from the increasing contribution to the GDP growth, the labor employment growth, and 
trading population, hotels and restaurants growth. Those mentioned above are three promising trends that will be able to expand employment opportunities in the hotel and restaurant sector as well as reduce the overall unemployment rate if the competencies required can be fulfilled by the workforce

\section{B. Human Resources Planning To Improve their Competitiveness}

Workforce planning consist of the process of knowing potential of individu and making sure that they are smoothly fitted into their assigned roles and overall system.[5] Managing human resources management through human capital management-means developing its knowledge, its competense, and its skills. [6]

Direction and manpower development strategy is "developing competitive economy and improvement in formal sector employment especially the core competence of the city, with the unemployment rate indicator in the open Phase II (2008-2013) is $15 \%$ and Phase III (2014-2018) open unemployment rate is $13.5 \%$. [7]

Tourism human resource development strategy will be focused on three aspects namely : Job opportunity expansion plan, the quality / competence improvement plan and entrepreneurship development. The proposed strategy is based on the field survey observation and focus group discussion and supported by the results of the study on the various national and regional employment policies in Indonesia.

\section{Job Opportunities Expansion Strategy}

Expansion of employment opportunities strategy and program can be implemented in several ways, such as:

a) Establish a policy that enable the private sector to make productive investments

b) Increase the participation of the public and private sector, include SMEs in the development of the tourism sector through the simplification of licensing procedures, improve SME access to funding sources, and facilitate improvement of SMEs business management capabilities. Encourage investment in the region through: simplification of licensing procedures and institutional investment in the region, optimize the planning, development and control of promotions to attract new investments, as well as incentives for investment activity in the region investment

c) Create conducive business climate for

d) Develop a database consisting of Bandung human resource supply and required profesion or competence by the market

e) Improve the quality of job market information and dissemination of job market information

f) Improving the quality of partnership with the private sector in the creation of employment opportunities
TABLE III. SWOT MATRIX OF BANDUNG TOURISM HR STANDARIZATION

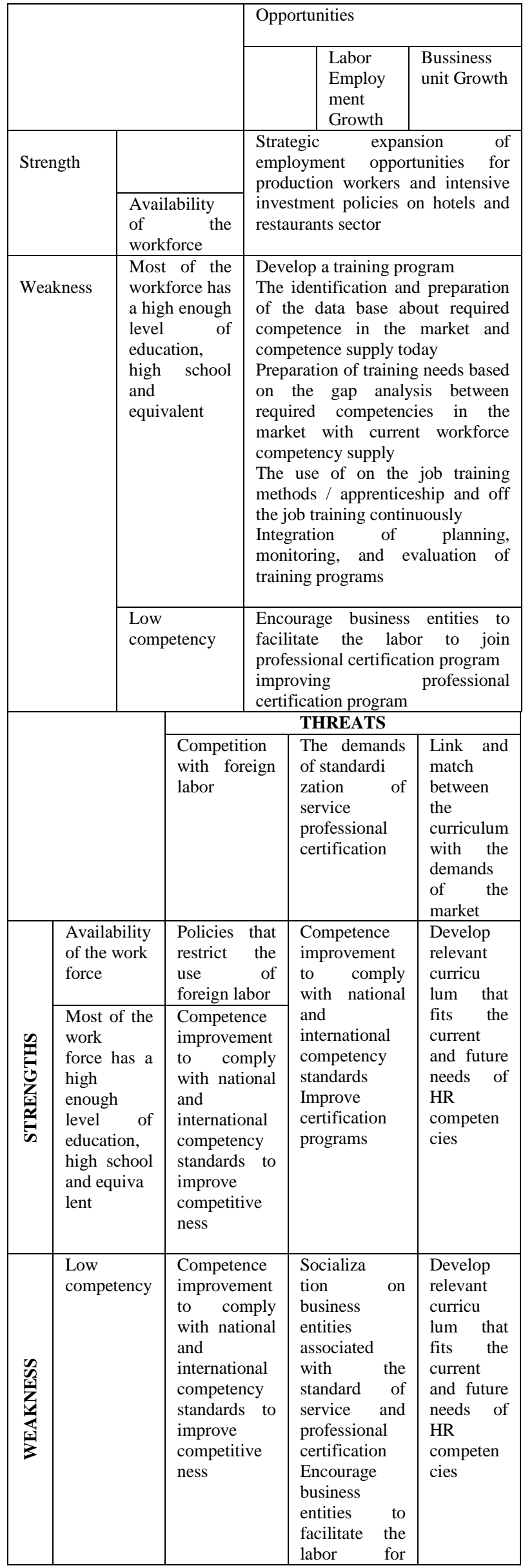




\begin{tabular}{|l|l|l|l|l|}
\hline & & $\begin{array}{l}\text { training and } \\
\text { join } \\
\text { professional } \\
\text { certification } \\
\text { program }\end{array}$ & \\
& $\begin{array}{l}\text { Low } \\
\text { number of } \\
\text { workers } \\
\text { who have } \\
\text { professional } \\
\text { certificate }\end{array}$ & $\begin{array}{l}\text { Develop and strengthen labor competency } \\
\text { standards } \\
\text { Develop the quality of educational } \\
\text { institutions and vocational training }\end{array}$ \\
$\begin{array}{l}\text { Develop the curriculum educational } \\
\text { institution or training institution in } \\
\text { accordance with the labor competency } \\
\text { standards SKKNI } \\
\text { Strengthen educational institutions to play an } \\
\text { active role as a certification institution }\end{array}$ \\
\hline
\end{tabular}

c. Source : data processed, 2015

\section{1) Quality/Competence Development Strategic} Plan

Deploy human resources as dynamic capability hold the potential for a sustained competitive advantage.(8) Strategy to improve the quality of tourism human resources are consisted of three aspects, namely: institutional capacity building strategy, the strategy of increasing the competence of labor, and partnership strategy.

\section{2) Standardization Program}

Develop a guideline on the use and implementation of SKKNI (Indonesia National Competence Standard) in the industry and establish policies for the industry in order to implement the HR development programs in their respective business entities, determine a minimum standard in the learning process

\section{3) Certification Program}

Develop a more effective professional certification system which provide benefits for the industry to implement it as part of internal human resources development program, develop a professional certification system to accommodate the existing standards at regional and international levels, strengthen the educational institutions to also play an active role as executor of HR certification, according to the field of expertise of graduates.

\section{4) Partnership strategy}

Partnership strategy by improving the quality of apprenticeship programs through the expansion of the coverage of apprenticeship and periodic evaluation of the implementation of the apprenticeship. Expand cooperation with partner companies abroad as a driving factor for the acceleration of the professional certification and standardization of service

\section{Enterpreneurship Development}

Strategies to be taken to develop entrepreneurship are:incorporating entrepreneurship as part of the education system in Indonesia, establishing cooperation / partnership with the business world ,building a business incubator centers for entrepreneurs and students, establishing cooperation between educational institutions and industries in the form of apprenticeship to equip students with the technical competence and business competence

\section{CONCLUSION}

HR employment potential of tourism is still wide open as seen from several indicators, namely the growth of the business activities of the tourism sector and the population growth of the business unit.

HR profile of tourism in the city has a number of strengths in terms of availability and the relatively high level of education (high school). The main weakness is the competence that is not in accordance with the demands of the industry and the lack of professional certificate.

HR planning tourism strategy will focus on three aspects, namely increasing the employment rate, improving the human resource quality / competence and entrepreneurship development.

\section{REFERENCES}

[1] Dinas Kebudayaan dan Pariwisata Jawa Barat. Statistical Report on Visitor Arrivals to Indonesia. 2008.

[2] Badan Pusat Statistik Kota Bandung. Kota Bandung dalam Angka Tahun 2013. 2014.

[3] World Economic Forum. Travel and Tourism Competitiveness Index. 2009.

[4] Rauch P. SWOT Analysis \& SWOT Strategy Formulation for Forest Owner Cooperation in Austris. Eur J For Res. 2007;126:413-20.

[5] Garg D, Rani K. Talent Management: Empirical Research Results. 2014;2(1):289-95.

[6] Rahman H, Mamun A Al. HRM Focus on Distinctive Human Capital and Strategy ofBuilding-Retaining Competitive Advantage. 2013;13(11).

[7] Pemerintah Kota Bandung. Rencana Pembangunan Jangka Menengah Daerah (RPJMD) Kota Bandung Tahun 2009-2013. 2009.

[8] Breznik L. Deploying Human Resource Capability for Sustainable Performance : a Dynamic Capabilities Framework. .561-70. 